\title{
研究ノート
}

\section{触法精神障がい者に対する看護阨の 態度の構成要件に関する質的研究}

松井 達也 $^{1)}$

2005年に医療観察法が施行され触法精神障がい者に対する看護が注目されている。触法精神障が い者に適切な看護を提供する上で彼らに対する態度を理解することが必要であるが，その態度につ いての構成要件については明らかにされていない。

そこで触法精神障がい者に対する看護師の態度の構成要件を明らかにすることを目的に触法精神 障がい者のケアを行っている 3 つの精神科病院で12名の看護師を対象に面接調査を実施した。そし てBerelsonの内容分析を用いて質的・㷌納的分析を行った結果，15個のカテゴリーが抽出された。

まず看護師は触法精神障がい者と出会い彼らと関係作りを行うが, これに関するカテゴリーが 5 個あった。次に臨床場面において治療的関わりを持つがこれに関するものが 4 個あった。さらに治 療を進める中で退院に向けた関わりを持っていたがこれに関するものが 2 個あった。そしてそれら の関わりの中で患者に対する様々な感情が生じていたがこれに関するものが 4 個あった。

触法精神障がい者に対する態度の構成要件は相反する洒值観が矛盾しながら存在するので，その バランスをいかにとるかが重要である。また触法精神障がい者に対する消極的態度を克服するため には彼らを深く理解し，彼らの看護に関する専門的な知識を持つことが大切である。さらに看護師 は彼らの退院後の地域支援システムの構築に寄与することが求められている。

キーワード 触法精神障がい者，看護，態度

\section{1．研究の背景}

近年，精神障がい者が何らかの犯罪に関わる場 合に「触法精神障がい者」という言葉が精神医療 関係者だけでなくマスコミでも取り上げられるよ うになった。触法精神障がい者とは「法に触れる 行為をしたが刑罰を科すのが不適当だと判断され た」精神障がい者のことを意味し，裁判で心神喪 失により責任能力がないため無罪となった場合, 心神耗弱により刑が減免された場合，起訴前の段 階で警察官・検察官の判断により不起訴となった 場合，矯正施設退所時に矯正施設長の判断により

1) 太成学院大学看護学部
保健所に通報される場合などがある（西口， 2002 ; 武井, 2003)。

2005年 7 月より「心神言失等の状態で重大な他 害行為を行った者の医療及び観察等に関する法 律」(以下医療観察法と記す）が施行され，これ に伴って, 触法精神障がい者に対する看護の一部 も，指定入院医療機関でガイドラインにそって行 われるようになった。しかし，指定入院医療機関 においてケアされる患者は，審判によってこの法 律による治療を受ける旨の決定を下された者に限 られ，全ての触法精神障がい者をケアできるわけ ではない。平成19年度の犯罪白書（法務省, 2007）によると，平成18年度に心神喪失を理由に 不起訴処分に付された被疑者540名と第一審に扮 
いて無罪になった者 5 名の計545名のうち医療観 察法の申し立てがあった者は351名であった。こ のうち入院決定 191 名, 通院決定 80 名を除くと, 医療観察法の適用のない者は274名となる。一方, 厚生統計協会（2008）によると，措置患者数は昭 和 45 年をピークに年々減少しているが，措置入院 のための申請・通報件数は近年, 増加傾向にあり, 平成18年度の新規措置入院患者数は5348名で, 仮 にこれらの患者が全て他害のおそれがあるとすれ ば，医療観察法の適用のない 274 名と合わせると， 5000名を超える触法精神障がい者が新たに一般精 神科病院で治療を受けることになる。またこの法 律による治療が終了した後には，これらの患者も 一般精神科病棟で治療を受けることになるので, 今後も医療観察法病棟だけでなく精神保健福祉法 の一般病棟も含めた病棟の果たす役割は大きい。

ところで触法精神障がい者の看護の実践につい て質的研究（松井，2008，2009）によると, 看護 師は入院時より患者に対して恐怖感や違和感と いった陰性感情を持ち, 行動制限の最小化がなか なか進められないケースがある一方で，患者の前 向きな変化を観察したり患者との信頼関係を深め ることで陰性感情が軽減するケースもあった。そ ういう点で触法精神障がい者の「法に触れる行為」 のために彼らに対して消極的な態度をとる場合も あるが，看護経験を積んだりありのままの患者の 姿を見ようという意識の持ち方といった看護師の 態度によってそれが変化していく可能性があると 考えられた。

このように触法精神障がい者に適切な看護を提 供するためにも彼らに対する態度を理解する必要 があるが，その構成要件については明らかにされ ていない。そこで本研究は触法精神障がい者に対 する看護師の態度の構成要件を明らかにすること を目的とした。

\section{2. 用語の定義}

\section{1 ) 触法精神障がい者}

武井 (2003) や西口（2002）の定義を参考に「法 に触れる行為をしたが刑罰を科すのが不適当だと 判断された」精神障がい者とし，医療観察法の対 象者と精神保健福祉法の他害のおそれ方方方措置 入院患者を包括するものとして定義した。

\section{2 ) 態度}

態度の研究は社会心理学が創始された当初から の中心的問題でありその概念については諸説あっ た。態度を「行動への準備状態」,「反応しょうと する傾向性」として取り扱う行動的側面を重視す る考え方（Manstead, 1990)，「態度は人，物，話 題に関する一般的で持続する正または負の感情を 指すために使われる」という感情的な側面を強調 する考え方 (Petty and Cacioppo, 1981)，「態度 は信念の上に築かれる」という認知的な基礎を重 視する考え方 (Ajzen, 1988)，行動的·感情的·認 知的な側面をすべて含むという考方方（三分法モ デル； Rosenberg and Hovland, 1960）など様々 であった。これらの諸説の中から態度の異なった 側面を最も良く表すことができる点（Breckler, 1984）やその測定方法を行動·認知·感情の言語的 表現と合理的に理論づけている点（Rosenberg and Hovland, 1960）から本研究ではRosenbergに よる三分法モデルを採用し，態度を「ある特定対 象に対し一定方法で反応する傾性とし，その主成 分は認知, 感情, 行動からなるもの」と定義した。

\section{3 . 研究方法}

\section{1 ）研究デザイン}

半構造化面接による質的帰納的研究とした。

\section{2 ) 研究対象}

触法精神障がい者のケアを行っている精神科病 院 3 施設の医療観察法病棟, 急性期治療病棟, 回 
復期病棟で勤務している15名の看護師に聞き取り 調査を依頼した。その結果, 調查のための勤務調 整がつかないため同意を得られなかった 3 名を除 く12名の看護師を研究対象とした。

\section{3 ）デー夕収集方法}

\section{(1) 調查期間}

$200 X$ 年Y月〜 $\mathrm{Y}+2$ か月

\section{(2) 調查方法}

対象者ごとに半構造化面接を実施した。触法精 神障がい者に対する態度ということで認知（どの ように捉えているか), 感情（どのように思って いるか), 行動（看護ケアの際にどのように接し ているか）について自由に話してもらった。研究 協力者から話が引き出しにくい時は，具体的な場 面，事柄などを例にあげて話すためのきっかけ作 りを行った。また面接の録音については調査協力 者全員の同意が得られたためICレコーダーで内 容を録音した。

\section{(3) データ分析方法}

Berelson（1954）の内容分析を参考に質的・帰 納的に分析した（Berelson, 1954 ; 舟島，1999）。 まず逐語録から触法精神障がい者に対する感情・ 認知・行動に関する記述を抜き出した。そして抜 き出した箇所の記述を整理，解釈しコードとした 後, 同様に複数の対象者間のコードを比較・検討 しそれらを統合するサブカテゴリー・カテゴリー を生成した。そしてカテゴリー相互の関係を検討 した。分析作業にあたっては, 指導教官 1 名のスー パーバイズを受け解釈の妥当性を確認した。また 研究対象者には逐語録, 報告書を随時手渡し, 誤 りや解釈のずれの有無を確認することで研究の妥 当性を高めた。

\section{(4) 倫理的配慮}

まず施設管理者に研究計画書を提示し研究の許 可を得た。次に病棟看護師長に対して研究計画書 を提示し面接の許可を得た。対象者の選定にあ たっては研究に参加しない場合でも不利益を受け
ないことを説明し，断りにくい状況を避けた。ま た対象者の面接に際して文書と口頭にて対象者に 改めて研究の趣旨説明を行った。そして面接途中 であっても中止して良いことや得られたデー夕は 研究以外には使用しないことを確約し承諾書を得 た。さらに対象者のプライバシーの保護に配慮す るために個室で面接を行った。得られたデー夕は 研究者自身が厳重に施錠管理し，逐語録の作成は 研究者自らが行った。逐語録, ワークシート,デー 夕表, 論文に記載する情報のうち個人や対象集団 の特定につながる記載を避け，匿名性を保持した。 また本研究は所属施設の研究倫理委員会の承認を 経て実施した。

\section{4. 結果}

\section{1 ) 対象者の背景}

男性 6 名, 女性 6 名で年齢は 20 ～50歳代であっ た。精神科看護歴は 1 年未満〜 30 年，1人あたり の面接時間は 22 ～41分であった。

\section{2 ）分析結果}

文章中の記号はカテゴリーは【】，サブカテ ゴリーは《》,コードは『』, 軸は \{ \} で示 した。

逐語録から50個のサブカテゴリーと15個のカテ ゴリーが生成され，各カテゴリーを検討する中で 触法精神障がい者に対する看護師の態度は以下の ような軸を持つカテゴリーから構成されていた。

まず看護師は触法精神障がい者と出会った時に 様々な情報から【患者の把握】を行い,【適切な 距離を保つこと】に心がけ,【経験と学習のバラ ンス】【ームとしての関わり】【個別的な関わり】 を使い分けて 関係づくり\}を行っていた。また 臨床場面において【服薬の必要性と困難】【他害 行為の内省】【強制治療の必要性と困難】【関連法 規の重視】といった 治療的関わり\}を持ってい た。さらに治療を進める中で【家族関係のサポー ト】【社会復帰のサポート】といった 退院に向 
けた関わり\}を持っていた。そしてそれらの関わ りの中で【恐怖心】【嫌悪感】【トレス】【親近感】 といった 患者に対する感情\} が生じていた。

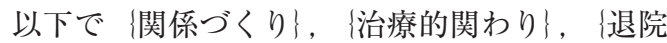
に向けた関わり\}，槵者に対する感情\} という軸 にそってそれぞれのカテゴリー，サブカテゴリー を説明する。ちなみにカテゴリー, サブカテゴリー は表 1 の通りである。

\section{(1) 関係づくり}

関係づくり\} に関するカテゴリーのうち最初 に重要な役割を果たすのは【情報の把握】であり, これは《イメージ把握の難しさ》《他害行為によ る評価》《疾患・症状による評価》《マスメディア の影響》《先入観を持たずに関わること》という
サブカテゴリーから構成された。例えば看護師は 『患者の中には入院前·入院時・入院後の 3 つのイ メージがあり，イメージが変わってくることもあ る』, 『実際の患者イメージと他害行為がマッチン グしないことがある』など《イメージ把握の難し さ》を感じていた。また『他害行為の内容によっ て患者への接し方が変わる』, 『患者へのケアのや りにくさは病気の内容による』, 『マスメディアの 報道で無意識に患者のことを犯罪者だと思う気持 ちはあるかもしれない』など他害行為·疾患·マス メディアの情報などが何らかの影響を与えてい た。しかし『(この疾患ならばこういう関わりを しなければならない）という先入観はなるべく持 たないようにしている』など《先入観を持たずに

表 1 触法精神障がい者に対する看護師の態度の構成要件

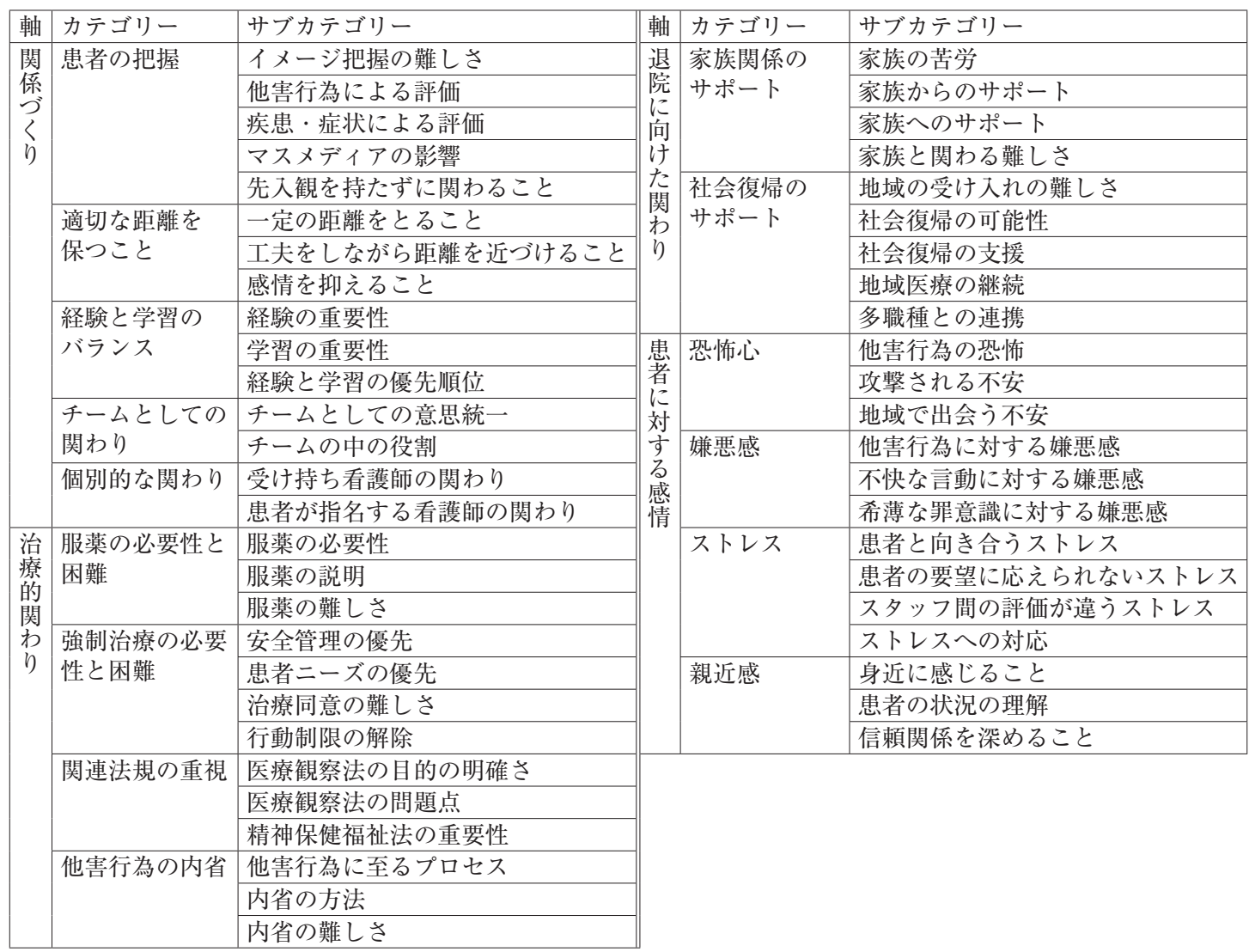

(著者作成) 
関わること》に留意していた。

次に患者と関係を深める上で大切なことが【適 切な距離を保つこと】であり，これは《一定の距 離をとること》《工夫をしながら距離を近づける こと》《感情を抑えること》というサブカテゴリー から構成された。患者をケアする際には『患者に 感情移入しすぎて近寄り過ぎてはいけない』など 《一定の距離をとること》を心がけ，『最初は興奮 されている患者もいるが，ちょっと時間を置いて 我に帰る時もあるので, その時にすっとお茶を 持っていく』など《工夫をしながら距離を近づけ ること》を実践していた。一方で『自分の感情を 出して患者さんに接することはあまりなく, どち らかと言うと感情を抑えながら話している』など 《感情を抑えること》を強いられる場合もあった。

さらに 関係づくり\}を行う上でどちらを優先 するかが常に問題になるのが【経験と学習のバラ ンス】であり,これは《経験の重要性》《学習の 重要性》《経験と学習の優先順位》というサブカ テゴリーから構成された。例えば『経験があれば, 目つきを見て今は調子が良くないからちょっと暴 力に至るんじゃないかと判断できる』など《経験 の重要性》が指摘される一方で『医療観察法の制 定など時代の流れに沿って変化している』《学習 の重要性》, 『ケアには個人の資質と経験と両方が 必要である』など《経験と学習の優先順位》を考 えながら行動していた。

最後に 関係づくり\}を行う上で使い分ける必 要があるのが, 【チームとしての関わり】【個別の 関わり】である。まず【チームとしての関わり】 は《チームとしての意思統一》《チームの中の役割》 というサブカテゴリーから構成された。例えば『患 者によってはチームとして一貫した態度を取って 対応をする場合もある』など《チームとしての意 思統一》を図ったり，『受け持ち看護師はいるが 日勤の数とかがあって受け持ちだけに任せてもそ んなに毎日来るわけではないので，看護師が分担 してチーム全体で患者をみられるようにする』な
ど《チームの中の役割》毎を果たすようにしてい た。次に【個別的な関わり】は《受け持ち看護師 の関わり》《患者が指名する看護師の関わり》と いうサブカテゴリーから構成された。例えば『社 会と患者を結ぶような話合いは受け持ちが前に出 てくるので, 最終的には受け持ちの責任というこ とになる』など《受け持ち看護師の関わり》によっ て治療計画などの踏み込んだ内容に対応する一方 で『男性看護師の方がしゃべりやすいしケアをし てもらいたいという要望があれば，担当看護師が 無理やりにケアするのではなく見守ることもあ る』など《患者が指名する看護師の関わり》といっ た個人的な信頼関係を大切にする場合もあった。

\section{(2) 治療的関わり}

\{治療的関わり $\}$ に関するカテゴリーは 4 個あっ た。このうち触法精神障がい者に限らず精神障が い者の看護に共通するのが【服薬の必要性と困難】 であり,これは《服薬の必要性》《服薬の説明》《服 薬の難しさ》というサブカテゴリーから構成され た。多くの看護師が『患者が精神的な病気ならば 薬を中心とした治療となる』など《服薬の必要性》 を感じ, 『薬の大切さの説明を治療計画に組み込 んで事あるごとに説明していく』『看護師が服薬 を管理して状態が良くなったり，退院が近くなっ た患者には詰め所まで自分で取りにきてもらって 内服してもらう』など段階を踏んで服薬の必要性 を理解してもらうなどの《服薬の説明》を行って いたが，『患者の服薬の自己管理には不安の方が 大きい』など《服薬の難しさ》を感じていた。

次にこれも精神障がい者の看護と共通するもの である【強制治療の必要性と困難】であるが，こ れは《安全管理の優先》《患者ニーズの優先》《治 療同意の難しさ》《行動制限の解除》というサブ カテゴリーから構成された。例えば『過去に予測 もできない事態が起こっているので最悪の状況を 考慮して事故防止に努める』など《安全管理の優 先》に努める一方で『身体拘束は一番きつい行動 制限であり隔離・身体拘束されている患者は自分 
で何もできない』など《患者ニーズの優先》も忘 れないようにしていた。また『最初の入院で病識 があるのはよっぽどのことだ』と考え，『治療の 同意を得られなかったとしても患者の利益や安全 のために絶対に正しいかどうかを考えて看護にあ たる』など《治療同意の難しさ》にも直面しなが ら『患者の病状が安定してくれば，カンファレン スで話し合って段階を追いながら，開放時間を延 長していく』など《行動制限の解除》に努めてい た。

またこちらも精神障がい者の看護と共通するも のである【関連法規の重視】であるが, これは《医 療観察法の目的の明確さ》《医療観察法の問題点》 《精神保健福祉法の重要性》というサブカテゴリー から構成された。例えば看護師は『医療観察法は ケアがプログラム化されて, 達成度をみながら次 の段階へと進む点で恵まれている』『医療観察法 は退院後のケアも充実している』など《医療観察 法の目的の明確さ》を指摘していた。一方で『医 療観察法は賛否両論の中でできあがったので触法 精神障がい者のためにきちんと整備されていな い』『医療観察法については勉強不足であまりわ からない』など《医療観察法の問題点》も指摘し ていた。さらに『精神保健福祉法は看護経験の有 無に関わらずしっかり勉強しなくてはいけない』 など《精神保健福祉法の重要性》も指摘していた。

最後に他の精神障がい者の看護と大きく違う点 が【他害行為の内省】であり，これは《他害行為 に至るプロセス》《内省の方法》《内省の難しさ》 というサブカテゴリーから構成された。例えば看 護師は『患者を疾患からどういう症状で他害行為 に及んだかと捉える』など患者が《他害行為に至 るプロセス》がどのようなものであるかを考えて いた。そして『他害行為の振り返りのためにはそ の患者といかに心が通じるかが重要である』など 心の通じ方や良いタイミングなど《内省の方法》 を工夫していた。しかし一方で『ケアの専門性が 必要だとは思うがどうしていいのかわからない』
など《内省の難しさ》にも直面していた。

\section{（3）退院に向けた関わり}

\{退院に向けた関わり\}のカテゴリーは 2 個あっ たが,このうち退院に向けての関わりは地域の社 会資源が不十分であることに加え, 精神障がい者 に対する地域住民の偏見が根強いことから今も難 しい課題となっている。ましてや触法精神障がい 者ということになるとより難しい現状にある。

退院に向けた関わり\}で何よりも重要である のが【家族関係のサポート】であり，これは《家 族の苦労》《家族からのサポート》《家族へのサポー ト》《家族と関わる難しさ》サブカテゴリーから 構成された。例えば触法精神障がい者の『家族は 入院するまでに様々な苦労や被害を受けている』 など《家族の苦労》や『患者と関わりたくない家 族が多い』『患者の家族が構いすぎる場合がある』 など《家族からのサポート》を評価しながら『退 院間近には家族に足を運んでもらわなければなら ないがなかなか進まない』など《家族と関わる難 しさ》を感じていた。そんな中で『患者が入院時 に様々な行動制限がかけられ家族にとっては ショックなので家族が理解できるように症状を説 明する』『家族との関係がうまくいってなければ 尚更家族の気持ちがすごく知りたい』など患者だ けでなく《家族へのサポート》も考慮していた。

さらに実際に 退院に向けた関わり\}を進める ためには【社会復帰のサポート】が重要であり， これは《地域の受け入れの難しさ》《社会復帰の 可能性》《社会復帰の支援》《地域医療の継続》《多 職種との連携》というサブカテゴリーから構成さ れた。看護師は触法精神障がい者の社会復帰に対 して『地域の人が患者に帰って来てほしくないと 思う』など《地域の受け入れの難しさ》を感じて いた。そして《社会復帰の可能性》については『ひ どい幻聴があっても周りのサポートがあればそれ なりの社会生活が営める』, 『患者の安易な社会復 帰は社会に迷惑をかける危険性がある』と考えな がらも，『退院した後，通院したりまた状態が悪 
くなったらすぐに受け入れられるようなシステム を取っていれば，そういう違和感はない』と捉え ていた。《社会復帰の支援》については『社会復 帰のためには経済面と家族からのサポートが大切 である』などと考えながら『患者が退院後, 通院 を続けられるかどうかが大切である』と《地域医 療の継続》の大切さを実感していた。そして《多 職種の連携》については『家族の受け入れが悪い 場合には医師に家族との面談の状況を聞いて, 必 要ならば家族に面談に来るように促す』など連携 を心がける一方で『退院支援のうち社会性や作業 性の面についてはソーシャルワーカーに任せてし まい積極的にできてない』など，うまく進んでい ない場合もあった。

\section{（4）患者に対する感情}

このように患者との関係作り, 治療的関わり, 退院に向けた関わりを通じて看護師は患者に対し て恐怖心，ストレスから親近感まで様々な 漶者 に対する感情\}を抱いていた。

患者に対する感情\} についてのカテゴリーは 4 個ありこのうち【恐怖心】は《他害行為の恐怖》 《攻撃される不安》《地域で出会う不安》というサ ブカテゴリーから構成された。看護師は『人に危 害を加えている患者に対峙するわけなので恐怖が ないというのは嘘になる』など《他害行為の恐怖》 を感じたり，『すごく興奮状態にあったり，体格 の良い男の方が暴れた場合には力では及ばないの で怖いなあと思う』など《攻撃される不安》を感 じていた。また『自分だけが被害を受けるならい いが家族に被害が及ぶことが怖い』など《地域で 出会う不安》も感じていた。

次に【嫌悪感】は《他害行為に対する嫌悪感》 《不快な言動に対する嫌悪感》《希薄な罪意識に対 する嫌悪感》というサブカテゴリーから構成され た。例えば看護師は『患者が残酷な他害行為や性 的な他害行為を行ったことに対してはクソとか ぞっとするという感情が出てくる』など《他害行 為に対する嫌悪感》を抱く場合があった。また『嫌
なことを言われたり暴力を受けたりすると一時的 に自分の感情も高まりそうになる』など《不快な 言動に対する嫌悪感》を抱く場合もあった。さら に『妄想のため罪の意識が全然ないことが腹立た しいし自分がこのくらいのことをしたということ を分かって欲しい』など《希薄な罪意識に対する 嫌悪感》を感じる場合もあった。

さらに患者と関わる中で様々な【ストレス】を 感じるが,これは《患者と向き合うストレス》《患 者の要望に応えられないストレス》《スタッフ間 の評価が違うストレス》《ストレスへの対応》と いうサブカテゴリーから構成された。例えば看護 師は『やってこられた他害行為を考えると患者と 向き合ったり注意を続けるのはつらい』など《患 者と向き合うストレス》を感じていた。また『患 者の退院について地域とよく話し合っても今の情 勢ではなかなかきつく患者の要望に応えられな い』など《患者の要望に応えられないストレス》 を感じたり，『行動制限の最小化について職員に よって評価が違う点が難しい』など《スタッフ間 の評価が違うストレス》を感じていた。さらに《ス トレスへの対応》としては例えば『白衣を着てい ると恐怖感を持たずに患者とちゃんと向き合え る』, 『医療観察法はやらなければならないことが きちんと決められており，その中でやっていくの でつらいと感じた事はあまりない』などストレス と上手に折り合いをつけられるよう努めていた。

そして触法精神障がい者との難しい関わりの中 で【親近感】を持つ場合もあり，これは《身近に 感じること》《患者の状況の理解》《信頼関係を深 めること》というサブカテゴリーから構成された。 例えば『患者の他害行為が重大でもなく一緒に生 活しているのを見れば，あんまりそう悪い人とは 思えない』など《身近に感じること》があった。 また『つらい環境が引き金となって発症してきた ことを聞くと，共感までいかなくても距離が縮ま るというか親近感がわいてくる』など《患者の状 況の理解》を通じて，そして『患者は時間をかけ 
て関わって初めてわかる場合もあった』など《信 頼関係を深めること》によって親近感が生じてい た。

\section{5. 考察}

\section{1 ) 構成要件における相反する価値観}

触法精神障がい者に対する態度の構成要件には 相反する価值観が矛盾しながら存在していた。例 えば【適切な距離を保つこと】では距離を一定に 保ちながら一方では信頼関係を深めなければなら ないし，【他害行為の内省】では再犯防止は避け られないものであることを認めつつも実践として 行うのは難しいと認めていた。また【強制治療の 必要性と困難】では安全を最優先する中で患者が 行動制限を受けることのつらさを引き受けなけれ ばならず，他害行為の防止を行いながら行動制限 の最小化を行うことが求められていた。【経験と 学習のバランス】は経験が大切であるがそれに頼 り過ぎると間違った方向に陥る危険性があること を示していた。さらに【患者の把握】では実際の 患者イメージと他害行為がマッチングしにくいた め患者のイメージが捉えにくく，そのことが触法 精神障がい者のケアを難しくしていることを示し ていた。そして【服薬の必要性と困難】では服薬 について必要性を理解してもらえるよう働きかけ る一方で，自己管理を進めるよりは全て管理して 強制的に内服してもらうことを優先している場合 もあった。また【チームとしての関わり】【個別 の関わり】ではチームとして意思統一を図ったり チームの中で与えられた役割を果たすことが重要 視されながら，時には個別に関わる必要性も指摘 されていた。感情面においても恐怖や違和感など の陰性感情がある一方で気の毒だという思いや親 近感などの陽性感情も見られた。

田原（2002）によると精神医療には「患者の病 気の治療」,「患者や障害者の福祉的サポート」,「社 会防衛的な仕事」の三つのタスクがある。この三 つは基本的に矛盾する関係にあり調和しづらく，
これらを同時に果たそうとするとそれぞれの機能 を著しく低下させることになる。そしてこの三つ のタスクをどう分化しどう統合していくかが重要 な問題であると指摘している（田原，2002）。三 つ目のタスクである「社会防衛的な仕事」は精神 障がい者による犯罪及び非社会的行為の被害から 一般市民を保護するという視点であるが（田原， 2002), 触法精神障がい者の場合「法に触れる行 為をした」という前提があるため一層その傾向が 強いと考えられる。

医療観察法の目的には「継続的かつ適切な医療 並びにその確保のために必要な観察及び指導を行 うことによって，その病状の改善及びこれに伴う 同様の行為の再発防止を図り，もってその社会復 帰を促進すること」とあるが，そこにも「同様の 行為の再発防止を図ること」と「社会復帰を促進 すること」という一見矛盾する目的の統合が求め られている。このことは触法精神障がい者だけで なく精神障がい者に関する態度全般に見られるも のである。例えば精神障がい者福祉基盤研究会 （1984）で用いられた精神障がい者に対する態度 の調查項目には「許容的 - 排除的」「治療的一非 （反）治療的」「科学的 - 非科学的」「庇護的 - 自 立尊重的」な観点があり，ほかにも人格障がい者 に対する態度尺度における「安全一攻撃を受けや すい」という観点（Bowers et al., 2006）, 救急精 神保健における態度尺度における「ケア一管理」 「安全な一危険な」という観点（Baker, Richards and Campbell, 2004）がある。このように触法精 神障がい者に対する態度の構成要件は相反する価 值観を持たざるをえず，それらのバランスをいか にとるかが重要であると言える。

\section{2 ）触法精神障がい者に対する消極的態度の克服}

前述の通り触法精神障がい者に対する態度は相 反する価值観のバランスをいかにとるかが重要で ある。しかし本研究においても《他害行為の恐怖》 《攻撃される不安》《地域で出会う不安》という【恐 
怖心】や《他害行為に対する嫌悪感》《不快な言 動に対する嫌悪感》《希薄な罪意識に対する嫌悪 感》という【嫌悪感】などの消極的な態度が多く 見られた。そしてそれらの消極的な態度の影響か ら《患者と向き合うストレス》などのストレスも 生じていた。

このことを克服するためには『話や内容を聞く と引いてしまうが，患者を前にすると，一人の患 者として捉えていこうと考える』『患者は他害行 為をしていると決めつけずに関わろうと思う』な どの《先入観を持たずに関わること》が必要であっ た。それには第一に触法精神障がい者の他害行為 にとらわれずに彼らをより媣く理解することが必 要である。患者の前向きな変化を観察したり患者 の精神症状に影響を与えている要因（患者の生活 歴, 発達歴など）を理解したり患者との信頼関係 を深めることで陰性感情も軽減するのである。他 の文献でも「看護師の患者に対する認知はnegativeな患者像の形成につながりながらも, 専門職 としての意識により患者を尊重し信頼関係を深め るに至っていた」(宮城，2007)，「看護師は患者 に頼られるようになる，関係が近づいたと感じる など関係の変化を認識し関係が深まることを感じ ていた」(熊地・宮本, 2005), 「否定的感情優位 の時期を経ることで患者への理解がより媣く多面 的になっていた」(小宮, 2005) と同様の指摘が 行われている。このことは患者についての与えら れた事実をあるがままに受け入れ患者をより深く 理解することで患者の多様性や個性を理解するこ とができたことを示している。

しかし患者の個性や多様性の重視だけで触法精 神障がい者に対する消極的態度を全て克服できる わけではない。例えば本研究でも『医療観察法病 棟以外で勤務する看護師は医療観察法について は, 勉強不足であまりわからない』『医療観察法 については, 研修を受けた経験はない』と感じて おり, 他の調査でも看護師は, 触法精神障がい者 の看護の重要性を実感しながら講習会や勉強会な
どの参加機会がないため問題解決の場がなく, 看 護の難しさや困難感を持つ傾向にある一方で医療 観察法に関する知識や学習経験, 触法精神障がい 者の看護経験を有する者ほどモデル事例の看護で 想定される困難感が少ないと指摘されていた（宮 城・森田・中谷, 2009)。

こう考えると松井（2010）も指摘しているよう に, 第二に触法精神障がい者の看護に関する専門 的な知識を持つことも必要である。例えば攻撃性 を管理するためのトレーニングを受けた場合, 攻 撃性を防御的なものと捉える傾向が小さくなった り (Palmstierna and Barredal, 2006), 周期的モ デルを用いた固有の文化や価值観の変化が患者の 回復のための前向きな力を生み出していたり (Cook, Philips and Sadler, 2005), 暴力治療プロ グラムの参加者に治療関係の発展がみられる (Schafer and Peternelj-Taylor, 2003) など, 看 護師が研修等を通じて専門的なケア技術を身につ けることで適切な看護ケアの提供が可能となって いた。さらに恐怖感については『白を着ている と恐怖感を持たずに患者とちゃんと向き合える』 『恐怖感は自分を奮い立たせて，大丈夫かなあと 思う程度で止める』『暴言に対しては「ああ言っ てるわ」と言うぐらいに思ってるので気にしない』 など《ストレスへの対応》を上手に行うことで陰 性感情に引きずられずうまく対応している場合も あった。

\section{3 ）触法精神障がい者に対する社会復帰に対する 態度 \\ 2005年 7 月に施行された医療観察法の目的は} 「継続的かつ適切な医療並びにその確保のために 必要な観察及び指導を行うことによって，その病 状の改善及びこれに伴う同様の行為の再発防止を 図り，もってその社会復帰を促進すること」であ り, 看護師も触法精神障がい者の社会復帰を促進 する姿勢が求められている。

本研究では社会復帰における地域での受け入れ 
については『地域の人が患者に帰って来てほしく ないと思う』『社会復帰のための施設がまだ充実 していない』と看護師は捉えつつも『ひどい幻聴 があっても周りのサポートがあればそれなりの社 会生活が営める』と捉えていた。また『安易な社 会復帰は社会に何か迷惑がかかる危険性がある』 と捉え，『社会復帰のためには経済面と家族から のサポートが大切である』『入院生活は人生のご く一部なので退院後の生活が重要だ』『退院に向 けての関わりがもっと必要だ』と考え，そのため には『患者の退院後, 通院を継続できるかが大切 である』と考えていた。そして社会復帰に目を向 けて関わったり，患者を支えるキーパーソンとし ての家族に関わるように働きかけていた。しかし 退院間近に家族に足をなかなか運んでもらえな かったり，退院支援や家族の複雑な問題について は医師やソーシャルワーカーに任せきりにしてし まうなど，家族や地域の調整には積極的に関わら ない面もあった。

そんな中で医療観察法の指定入病棟では社会復 帰に対する積極的な働きかけが見られている。本 研究でも『医療観察法は, 再犯防止と同時に社会 復帰も進めるのが大前提である』『医療観察法病 棟で患者が退院するのを見て社会復㷌の可能性は あると思う』『医療観察法は退院後のケアも充実 している』など社会復帰に関しても《医療観察法 の目的の明確さ》が指摘されていた。一方で『医 療観察法は, 賛否両論の中でできあがったので, 触法精神障がい者のためにきちんと整備されてい ない』『医療観察法は，「他害行為をするので，病 院に放り込もう」と社会防衛論的な考え方で運用 されている』など社会復帰に関して《医療観察法 の問題点》も指摘されていた。他の研究でも地元 住民の根強い反対などは改善されておらず地域の 受け血の体制は不十分であり社会復帰には困難を 要すると指摘されていた（美濃ら，2008）。

このように触法精神障がい者の社会復帰に関し ては入院病棟における看護師の態度も 1 つの主要
な要素ではあるが, 医療観察法施行後も地域資源 の整備は不十分であり，地域の医療機関，福祉施 設，地域住民の意識といった地域の受け血の体制 作りに看護職種としていかに関わるかが重要であ ると言える。

\section{6 . 研究の課題}

本研究における限界は, 研究対象者が 3 施設の 12 名と限定されていたことであった。今後は複数 の施設にわたって対象者数を増やし, 触法精神障 がい者に対する態度の構成要件をより妥当性のあ るものとする必要がある。また近年，触法精神障 がい者に対しても他の精神障がい者と同様に社会 復帰の促進が図られており, 触法精神障がい者の 地域支援における看護職の役割を明らかにするこ とも今後の課題であると言える。

\section{謝辞}

本研究は医療科学研究所の研究助成金により行 われました。面接にご協力下さいました対象者の 皆様をはじめご支援いただきました皆様方に媣く 感謝いたします。

\section{参考文献}

Ajzen I (1988) Attitudes, Personality, and Behavior. Milton Keynes : Open University Press.

Baker JA, Richards DA and Campbell M (2004) "Nursing Attitudes towards Acute Mental Health Care : Development of a Measure Tool," Journal of Advanced Nursing. 49 (5) : 522-529.

Berelson B (1954) "Content Analysis," in Handbook of Social Psychology, volume I: Theory and Method; ed. by Lindzey G. 488-522 ; Cambridge, Massachusetts : Addison-Wesley.

（邦訳 ガードナー・リンゼイ著，稲葉三千男，金圭煥 訳（1957）「内容分析」『社会心理学講座 7 大衆と マス・コミュニケーション』みすず書房)

Bowers L, Carr-Walker P, Allan T, Callaghan P, Nijman H and Paton J (2006) "Attitude to Personality Disorder among Prison Officers Working in a Dangerous and Severe Personality Disorder Unit," International Journal of Law and Psychiatry. 29 (5) : 333-342.

Breckler SJ (1984) “Empirical Validation of Affect, 
Behavior, and Cognition as Distinct Composite Elements of Attitude," Journal of Personality and Social Psychology. 47 : 1191-1205.

Cook NR, Phillips BN and Sadler D (2005) “The Tidal Model as Experienced by Patients and Nurses in a Regional Forensic Unit," Journal of Psychiatric and Mental Health Nursing. 12 (5) : 536-540.

Manstead ASR (1990) "Attitudes," in The Blackwell Dictionary of Cognitive Psychology ; ed. by Eysenck MW. 30-35 ; Oxford : Basil Blackwell.

（邦訳 マンステッド ASR 著, 野島久雄訳 (1998)「態 度」『認知心理学事典』248-255, 新曜社)

Palmstierna T and Barredal E (2006) "Evaluation of the Perception of Aggression Scale (POAS) in Swedish Nurses," Nordic Journal of Psychiatry. 60 (6) : 447-451.

Petty RE and Cacioppo JT (1981) Attitudes and Persuasion: Classic and Contemporary Approaches. Iowa: Dubuque.

Rosenberg MJ and Hovland CI (1960) “Cognitive, Affective, and Behavioral Composite Elements of Attitudes," in Attitude Organization and Change ; An Analysis of Consistency among Attitude Composite Elements ; ed. by Rosenberg MJ. 1-14 : U.S.A. : Yale University Press.

Schafer P and Peternelj-Taylor C (2003) “Therapeutic Relationships and Boundary Maintenance : The Perspective of Forensic Patients Enrolled in a Treatment Program for Violent Offenders," Issues in Mental Health Nursing. 24 (6-7) : 605-625.

厚生統計協会（2008）「精神障がい者の医療」『国民衛 生の動向·厚生の指標』臨時増刊55（9）：113-114

精神障がい者福祉基盤研究会（岡上和雄代表, 宗像恒 次他）（1984）『精神障がい者の社会復帰・福祉施策形 成基盤に関する調査』三菱財団社会福祉助成金報告 書

小宮敬子（2005）「看護師がケア場面で体験した否定的 感情の様相に関する研究」『お茶の水医学雑誌』53(4): 77-96

熊地美枝, 宮本真巳（2005）「触法精神障がい者との援 助関係に関する研究」『平成16年度厚生労働科学研究
費補助金「触法行為を行った精神障がい者の精神医 学的評価·治療・社会復帰等に関する研究」総括·分担 報告書』542-550

武井満（2003）「触法精神障がい者をめぐる司法精神医 学的課題」『精神科看護』 $132: 36-41$

田原孝（2002）「日本の精神医療はこれで良いのか」福 岡県弁護士会精神保健委員会『触法精神障害者の処 遇と精神医療の改善』125-137, 明石書店

西口芳伯 (2002)「法と精神医療」新宮一成, 角谷慶子『共 生の論理をもとめて 1 精神障害とこれからの社会』 150-218, ミネルヴァ書房

舟島なをみ（1999）「内容分析」『質的研究への挑戦』 42-53, 医学書院

法務省（2007）「精神障がいのある犯罪者」『平成19年 度犯罪白書』, 124-128, 法務省, 東京

松井達也（2008）『触法精神障がい者に対する看護の実 践』平成19年度神戸大学大学院 医学系研究科 修 士論文

松井達也（2009）「触法精神障がい者に対する看護師の 感情面での経験」『日本精神保健看護学会誌』18(1): 114-120

松井達也 (2010)「ステレオタイプの概念分析 触法精 神障がい者に対するステレオタイプに焦点を当てて」 『大阪府立大学看護学部紀要』16 (1)：40-47

美濃由紀子, 牧野貴樹, 宮本真巳ほか (2008)「医療観 察法における指定入院医療機関スタッフの意識調査 開棟前の期待や危惧にもとづいた開棟後アンケート

調査より」『日本精神科看護学会誌』51（3）：490-494

宮城純子（2007）「重大な触法行為を行った精神障がい 者に対する看護師の認知と看護実践」『日本社会精神 医学会雑誌』15：147-158

宮城純子, 森田展影, 中谷陽二（2009）「触法精神障が い者に対する看護関係者の認知」『日本社会精神医学 会雑誌』18：6-17

山口勧（1994）「態度変化」『ベーシック現代心理学 7 社会心理学』67-79, 有斐閣

（2010年5月11日受付，2010年11月30日採用）

連絡先 : 松井達也

t-matsui@tgu.ac.jp 


\title{
Nurses' Attitudes toward Mentally Disordered Offender (MDO) Patients : A Qualitative Study of Composite Elements
}

\author{
Tatsuya Matsui, M.S. ${ }^{1)}$
}

\begin{abstract}
After the passing of new legislation on mentally disordered offender (MDO) patients in 2005, care for MDO patients has become a matter of concern in Japan. This study aims to identify composite elements of nurses' attitudes toward MDO patients. Open-ended interviews were conducted with 12 nurses caring for MDO patients at three psychiatric hospitals. Data were analyzed qualitatively and inductively according to the methodology of Berelson, and 15 categories were extracted.

Five of the extracted categories related to relationships between nurses and MDO patients. Four categories related to medical treatment for MDO patients were extracted. Two categories related to MDO patients returning to communities were extracted. The remaining, four categories related to feelings about MDO patients.

Nurses must resolve their conflicted feelings about MDO patients, and should learn more about MDO patients in order to improve their nursing for them and overcome their negative attitudes towards them. Furthermore, it is necessary to establish regional support systems for MDO patients.
\end{abstract}

Keywords : Mentally disordered offender patients, Nursing, Attitudes

${ }^{1)}$ Faculty of Nursing, Taisei Gakuin University 